\begin{tabular}{|l|l|l||}
\hline \multicolumn{2}{|c|}{ PublisherInfo } \\
\hline \hline PublisherName & $:$ & BioMed Central \\
\hline \hline PublisherLocation & $:$ & London \\
\hline \hline PublisherImprintName & $:$ & BioMed Central \\
\hline \hline
\end{tabular}

\title{
Mixed-sex embryo controversy
}

\begin{tabular}{|l|l|l||}
\hline \multicolumn{2}{|c|}{ ArticleInfo } \\
\hline \hline ArticleID & $:$ & 4808 \\
\hline \hline ArticleDOI & $:$ & $10.1186 /$ gb-spotlight-20030709-01 \\
\hline \hline ArticleCitationID & $:$ & spotlight-20030709-01 \\
\hline \hline ArticleSequenceNumber & $:$ & 160 \\
\hline \hline ArticleCategory & $:$ & Research news \\
\hline ArticleFirstPage & $:$ & 1 \\
\hline \hline ArticleLastPage & $:$ & 3 \\
\hline \hline & & RegistrationDate : 2003-7-9 \\
\hline ArticleHistory & $:$ & OnlineDate \\
\hline \hline ArticleCopyright & $:$ & BioMed Central Ltd2003-7-9 \\
\hline \hline ArticleGrants & $:$ & \\
\hline \hline ArticleContext & $:$ & 130594411 \\
\hline \hline
\end{tabular}


Fertility scientists are joining ethicists and antiabortion activists in criticizing a researcher's claim that he has created chimeric human embryos that are part male and part female. Scientists doubt the usefulness of work presented by Norbert Gleicher last week at the annual meeting of the European Society for Human Reproduction and Embryology (ESHRE) in Madrid. ESHRE condemned the work immediately after it was presented.

Gleicher, who could not be reached for comment, reported that he and his colleagues at the Center for Human Reproductionin Chicago had transplanted one, two, or three cells from male embryos into 21 one-day-old female human embryos. His rationale was that the Y chromosome in some cells made the fate of the cells simple to monitor. Twelve chimeric embryos developed normally, he said, while four died immediately after the cell transplant and five developed into abnormal blastocysts.

The chimeras were destroyed after 6 days, at the blastocyst stage, Gleicher said. He argued that the purpose of the work was to show that creation of chimeras might be a way to repair genetic disorders. He also said he plans to patent the technique.

In addition to ethical questions, Gleicher's report has prompted scientific skepticism about whether creation of chimeras is a reasonable approach to gene therapy. How, for example, could an embryo doctor ensure that the healthy cells end up in the right organs so that they could counteract the disease mutation that would remain in cells from the original embryo? "It is biologically flawed and would in most cases not lead to the endpoint he is seeking," reproductive biologist Lynn Fraser, who heads an ESHRE scientific committee, told us.

"They needed a marker so that they could determine the distribution of the added cells. Was the Y chromosome the only possibility? Doubtful," said Thomas Murray, who heads The Hastings Center, a bioethics think tank in Garrison, NY.

Françoise Shenfield, coordinator of the ESHRE Special Interest Group on Ethics and Law, said the work was not only ethically objectionable, it was scientifically and medically questionable. "There are potential long-term health risks for any child if this was used in a clinical setting. I cannot conceive of any situation in which this particular technique would be acceptable, and if it cannot be applied there is not much use in experimenting with it," she said.

Murray argues that the work demonstrates the gulf between most people, who think of human embryos as special, and the clinicians and researchers, who work with human embryos and who regard them as blobs of cells like any other tissue. "The researchers in this case were either stunningly naive about the likely public reaction - or got exactly the publicity boost that they sought," he said.

For Arthur Caplan, who heads the Center for Bioethics at the University of Pennsylvania, Gleicher's report is the inevitable product of 20 years of complete absence of regulation in the reproductive technology industry. "The federal government decided years ago that the subject was too hot to handle, and private entities have fended off all attempts at ethical accountability for the field," he said. "This type of experiment makes it very clear why that situation must change." 


\section{References}

1. European Society for Human Reproduction and Embryology 2003, [http://www.eshre.com/ecm/ mainM.asp?r=156]

2. Center for Human Reproduction, [http://www.centerforhumanreprod.com/about.html]

3. Kamenetsky H: Chimera conflict The Scientist, December 10, 2002., [http://www.the-scientist.com/ news/20021210/04/]

This PDF file was created after publication. 